\title{
Regulation of molecular pathways in the Fragile X Syndrome: insights into Autism Spectrum Disorders
}

\author{
Silvia De Rubeis • Claudia Bagni
}

Received: 20 November 2010 / Accepted: 7 July 2011 /Published online: 13 August 2011

(C) The Author(s) 2011. This article is published with open access at Springerlink.com

\begin{abstract}
The Fragile X syndrome (FXS) is a leading cause of intellectual disability (ID) and autism. The disease is caused by mutations or loss of the Fragile X Mental Retardation Protein (FMRP), an RNA-binding protein playing multiple functions in RNA metabolism. The expression of a large set of neuronal mRNAs is altered when FMRP is lost, thus causing defects in neuronal morphology and physiology. FMRP regulates mRNA stability, dendritic targeting, and protein synthesis. At synapses, FMRP represses protein synthesis by forming a complex with the Cytoplasmic FMRP Interacting Protein 1 (CYFIP1) and the cap-binding protein eIF4E. Here, we review the clinical, genetic, and molecular aspects of FXS with a special focus on the receptor signaling that regulates FMRP-dependent protein synthesis. We further discuss the FMRP-CYFIP1 complex and its potential relevance for ID and autism.
\end{abstract}

Keywords Fragile X syndrome · Autism · FMRP. Protein synthesis $\cdot$ mRNPs $\cdot$ mRNA metabolism $\cdot$ Synaptic plasticity

S. De Rubeis · C. Bagni

Center for Human Genetics, Katholieke Universiteit Leuven,

3000 Leuven, Belgium

S. De Rubeis $\cdot$ C. Bagni

Department of Molecular and Developmental Genetics, Flanders Institute for Biotechnology (VIB),

3000 Leuven, Belgium

C. Bagni $(\square)$

Department of Experimental Medicine and Biochemical Sciences, University "Tor Vergata",

00133 Rome, Italy

e-mail: claudia.bagni@uniroma2.it

e-mail: claudia.bagni@med.kuleuven.be

\section{Fragile $X$ and fragile $X$ tremor ataxia syndromes:} clinical phenotypes

The Fragile X syndrome (FXS) is the most frequent form of inherited intellectual disability (Jacquemont et al. 2007). Patients with FXS have physical features, such as large ears, an elongated face, and a high arched palate, which have been reported in $60 \%$ of prepubertal FXS boys. Other symptoms include connective tissue anomalies, which can lead to a prolapsed mitral valve, scoliosis, flat feet, and joint laxity and macro-orchidism in boys. Macro-orchidism affects about $90 \%$ of boys with FXS (Jacquemont et al. 2007) but the causes are still largely unknown. In addition, subtle dysfunctions of the hypothalamic-pituitary-thyroid axis have been reported in FXS patients (Bregman et al. 1990). Studies performed in Fmrl KO animals did not reveal altered levels of the follicle-stimulating hormone, but an increase of Sertoli cell proliferation during testis development (Slegtenhorst-Eegdeman et al. 1998).

Patients display a broad spectrum of cognitive and behavioral deficits. The developmental delay is the most consistent feature, with a mean IQ of 42 in boys and severe mental retardation in about $25 \%$ of cases. Since the disorder is $\mathrm{X}$-linked and the penetrance is variable, females are usually in a low-normal range, with an IQ ranging from 70 to 90 (Jacquemont et al. 2007). Moreover, epilepsy has been described in $13-18 \%$ of boys and $4 \%$ in girls, but the seizures tend to resolve during childhood (Berry-Kravis 2002). Despite the severe neurobehavioral symptoms, the anatomical studies only revealed minor abnormalities in post mortem brains from FXS patients (Hallahan et al. 2011; Reiss et al. 1995). The most prominent neuroanatomical feature is the dysgenesis of dendritic spines that appear longer and thinner than normal, likely due to a developmental delay in spine dynamics and in transition from immature 
to mature spines (Cruz-Martin et al. 2010; Irwin et al. 2001). FXS is also considered the most common monogenic cause of Autism Spectrum Disorder, ASD (Hatton et al. 2006) (see below).

FXS is mainly due to a triplet repeat expansion in the $5^{\prime}$ untranslated region $\left(5^{\prime} \mathrm{UTR}\right)$ of the Fragile $\mathrm{X}$ mental retardation 1 (FMR1) gene, located on chromosome Xq27-3. In over $90 \%$ of patients, a CGG triplet in the $5^{\prime}$ UTR of the gene is expanded to over 200 copies, leading to hypermethylation of the CGG, transcriptional silencing, and abolished production of the Fragile X Mental Retardation Protein (FMRP) (Jacquemont et al. 2007). Cases of FXS due to point mutations or microdeletions are very rare. A severe FXS form has been documented in a patient with a mutation in the coding region, leading to the substitution of Isoleucine 304 to Asparagine (Ile304Asn) (De Boulle et al. 1993). A few cases of deletions in the coding regions have also been identified (Gedeon et al. 1992; Meijer et al. 1994; Mila et al. 2000; Wohrle et al. 1992).

The CGG triplet region is highly polymorphic in the population. Normal alleles (5-44 CGG copies) are stably transmitted to the offspring; "grey-zone" alleles (45-54 copies), and "premutation" alleles (55-200 copies) are rather unstable and can evolve into a "full mutation" $(>200$ repeats) during the maternal transmission. The risk of transmitting a full mutation allele is a function of the repeat length (Hagerman and Hagerman 2002).

Premutation alleles do not lead to FXS, but can cause two distinct pathologies, namely the Fragile X-associated Premature Ovarian Insufficiency (FX-POI) and the Fragile $\mathrm{X}$-associated Tremor/Ataxia Syndrome (FXTAS). FX-POI is defined as menopause or hypoestrogenic amenorrhea occurring prior to age 40 . Premature ovarian failure occurs in about $1 \%$ of the general population, and about $6 \%$ of women with this disease are positive for premutation alleles (Hagerman and Hagerman 2002). FXTAS is a neurodegenerative disorder mainly featured by progressive cerebellar ataxia and intention tremor. The patients also show neuropsychiatric alterations (anxiety, hostility, depression) and cognitive dysfunctions, ranging from mild frontal executive and memory deficits to global dementia (Hagerman and Hagerman 2002; Jacquemont et al. 2007). Although FXTAS mainly affects men, clinical cases of women with FXTAS have also been reported (Hagerman et al. 2004).

The molecular mechanisms underlying the premutation pathologies are not fully understood. A consistent molecular feature is the elevation of FMR1 mRNA levels (Allen et al. 2004; Kenneson et al. 2001; Tassone et al. 2000) due to increased transcription (Tassone et al. 2007). Nevertheless, carriers of premutation alleles show decreased levels of FMRP (Brouwer et al. 2008; Entezam et al. 2007; Kenneson et al. 2001; Primerano et al. 2002) caused by reduced translational efficiency of the FMR1 mRNA due to the CGG expansion in the $5^{\prime}$ UTR (Feng et al. 1995; Primerano et al. 2002) as well as polyadenylation (Tassone et al. 2011). Additionally, FMR1 mRNA has been detected in the ubiquitin-positive intranuclear inclusions found in neurons and astrocytes throughout the brain of FXTAS patients (Greco et al. 2002; Tassone et al. 2004). The intranuclear foci were consistently observed in model organisms for FXTAS, both mouse (Berman and Willemsen 2009) and Drosophila (Jin et al. 2007; Sofola et al. 2007). Remarkably, the number of inclusions correlates with the size of the CGG expansion (Greco et al. 2006; Greco et al. 2002). These observations led to the hypothesis that the premutation causes a gain-of-function phenotype due to RNA toxicity (Brouwer et al. 2009; Garcia-Arocena and Hagerman 2010; Tan et al. 2009).

Fragile X syndrome and Autism Spectrum Disorder FXS is the most common monogenic cause of Autism Spectrum Disorder (ASD), a heterogenous group of neurodevelopmental pathologies affecting approximately 37 individuals in 10,000 (Fombonne 2005) and observed in more than $40 \%$ of patients with intellectual disability (Moss and Howlin 2009). ASD is diagnosed by clinical assessment of three core dysfunctions before 3 years of age: atypical social behavior, deficits in verbal and non-verbal communication, and presence of repetitive and highly restricted interests (Geschwind and Levitt 2007). These disturbances range from the Autistic Disorder (13 in 10000), through a Pervasive Developmental Disorder Not Otherwise Specified (PDD-NOS, 20.8 in 10000), to a less frequent form, the Asperger syndrome (2.6 in 10000) (Fombonne 2005). However, while children with Autistic Disorder and PDD-NOS have specific impairments in the three domains (language, social and interests) and can be mentally retarded, individuals with Asperger Syndrome have a proper use of language and are not affected by cognitive delay (Abrahams and Geschwind 2008).

About $25 \%$ of FXS boys and $6 \%$ of girls have been reported to meet criteria for ASD, while $1-2 \%$ of patients affected by ASD have FXS (Abrahams and Geschwind 2008; Hatton et al. 2006). Recent reports estimated that about 30\% of FXS subjects meet criteria for Autistic Disorder and 30\% for PDD-NOS (Harris et al. 2008). However, up to $90 \%$ of children with Fragile X display behavioral alterations which resemble ASD, such as social anxiety, gaze avoidance, sensory hypersensitivity, tactile defensiveness, stereotypic movements, poor motor coordination, delayed speech development, and echolalia (Belmonte and Bourgeron 2006; Hernandez et al. 2009). The basis of reduced penetrance of ASD in patients with FXS is still unclear; nevertheless, the cognitive delay is more severe in FXS children with ASD, and children with FXS and ASD are more likely to have a secondary medical problem compared to those with FXS alone (Garcia-Nonell et al. 2008). 


\section{Molecular functions of FMRP}

Fragile X syndrome is caused by the absence of the Fragile $\mathrm{X}$ Mental Retardation Protein (FMRP). FMR1 mRNA is ubiquitously expressed, and high levels have been detected in brain and gonads - the organs mainly affected in FXS patients (Tamanini et al. 1997). Considering the correlation between FMRP expression and cognitive abilities, the molecular role of this protein has been deeply investigated in brain.

Functionally, FMRP belongs to the family of RNA binding proteins (RBPs), which shuttle between nucleus and cytoplasm. As other RBPs, FMRP interacts with protein partners and RNAs forming large messenger ribonucleoparticles (mRNPs). FMRP has four RNA binding domains and can associate with messenger RNAs, as well as noncoding RNAs, such as the Brain Cytoplasmic 1 (BC1) RNA and microRNAs (Edbauer et al. 2010; Gabus et al. 2004; Johnson et al. 2006; Zalfa and Bagni 2005; Zalfa et al. 2003). Among the best characterized FMRP targets are $\alpha$-CaMKII, Arc, Map1b, Sapap4, and PSD-95 mRNAs (Bassell and Warren 2008) (Table 1). While some mRNAs such as $P S D-95$ are directly recognized by FMRP (Zalfa et al. 2007), some others are recruited through base-pairing with noncoding RNAs such as $B C 1$ (Zalfa et al. 2005; Zalfa et al. 2003) and microRNAs (Edbauer et al. 2010). Furthermore, FMRP mRNPs orchestrate the posttranscriptional destiny of bound mRNAs by regulating their stability, localization, or translation (Bagni and Greenough 2005; De Rubeis and Bagni 2010) (Table 1).

Effects of FMRP on mRNA stability FMRP can regulate mRNAs half-life, either by favoring or preventing mRNA decay (De Rubeis and Bagni 2010). Two high-throughput screenings revealed that FMRP affects the expression of target mRNAs. First, Warren and colleagues found that the levels of 144 target mRNAs were changed in lymphoblastoid cells from FXS patients (Brown et al. 2001). In a second study, Eberwine and collaborators reported decreased expression levels of at least 2 mRNAs ( $p 40 / L R P$ and GRK4 mRNAs) in the hippocampus of Fmrl KO mice (Miyashiro et al. 2003). Furthermore, loss of FMRP may affect the expression of mRNAs encoding $\mathrm{GABA}_{\mathrm{A}}$ receptors. The expression of $\delta$ subunit mRNA, previously identified as FMRP target by Miyashiro et al. (2003), was found to be reduced in FMRP-deficient neurons in a

Table 1 FMRP functions and target mRNAs

\begin{tabular}{|c|c|c|c|c|c|}
\hline $\begin{array}{l}\text { FMRP } \\
\text { Function }\end{array}$ & Regulation & Target MRNAS & $\begin{array}{l}\text { Where FMRP affects } \\
\text { their regulation }\end{array}$ & $\begin{array}{l}\text { How FMRP affects } \\
\text { their regulation }\end{array}$ & References \\
\hline \multirow[t]{2}{*}{ Stability } & + & PSD-95 & Mouse hippocampus & Activity-dependent & Zalfa et al. 2007 \\
\hline & + & GABA subunits & Mouse cortex; Drosophila. & $\begin{array}{l}\text { mRNA levels are reduced } \\
\text { but a direct evidence on } \\
\text { their different stability } \\
\text { is not available }\end{array}$ & $\begin{array}{l}\text { Gantois et al. 2006; } \\
\text { D'Hulst et al. 2006; } \\
\text { Dictenberg et al. } 2008\end{array}$ \\
\hline \multirow[t]{4}{*}{ Transport } & + & Map1B & Primary hippocampal neurons & Activity-driven transport & Dictenberg et al. 2008 \\
\hline & + & $\alpha$-CaMKII & Primary hippocampal neuron & Activity-driven transport & $\begin{array}{l}\text { Dictenberg et al. 2008; } \\
\text { Kao et al. } 2010\end{array}$ \\
\hline & + & Sapap4 & Primary hippocampal neurons & Activity-driven transport & Dictenberg et al. 2008 \\
\hline & + & Rgs5 & Hippocampal slices & Basal mRNA localization & Miyashiro et al. 2003 \\
\hline \multirow[t]{5}{*}{ Translation } & - & Map1B & $\begin{array}{l}\text { Mouse brain and hippocampal } \\
\text { slices; human FXS } \\
\text { lymphoblastoid cells; }\end{array}$ & Basal and activity-dependent & $\begin{array}{l}\text { Brown et al. 2001; } \\
\text { Zalfa et al. 2003; } \\
\text { Lu et al. 2004; } \\
\text { Hou et al. } 2006\end{array}$ \\
\hline & - & Arc & $\begin{array}{l}\text { Mouse brain; hippocampal } \\
\text { slices; synaptoneurosomes }\end{array}$ & Basal and activity-dependent & $\begin{array}{l}\text { Zalfa et al. 2003; } \\
\text { Park et al. 2008 }\end{array}$ \\
\hline & - & $\alpha$-CaMKII & $\begin{array}{l}\text { Mouse brain; hippocampal } \\
\text { slices; synaptoneurosomes }\end{array}$ & Basal and activity-dependent & $\begin{array}{l}\text { Zalfa et al. 2003; } \\
\text { Hou et al. 2006; } \\
\text { Muddashetty et al. 2007; } \\
\text { Kao et al. } 2010\end{array}$ \\
\hline & - & App & Cortical synaptoneurosomes & $\begin{array}{l}\text { Basal and activity-dependent; } \\
\text { antagonistic effects with } \\
\text { HnRNPC }\end{array}$ & $\begin{array}{l}\text { Westmark and Malter 2007; } \\
\text { Lee et al. } 2010\end{array}$ \\
\hline & - & PSD-95 & Cortical synaptoneurosomes & Activity-dependent & $\begin{array}{l}\text { Todd et al. 2003; } \\
\text { Muddashetty et al. } 2007\end{array}$ \\
\hline
\end{tabular}

Three well-characterized FMRP functions, namely mRNA stability, transport and translation, are indicated. Established FMRP target mRNAs are listed. Other studies on additional putative mRNA targets are cited in the text 
genome-wide expression profiling study (Gantois et al. 2006) as well as by in situ hybridization studies (Dictenberg et al. 2008). Additionally, the mRNAs encoding 8 out of 18 known GABA subunits $(\alpha 1, \alpha 3, \alpha 4, \beta 1, \beta 2, \gamma 1, \gamma 2$ as well as the above mentioned $\delta$ ) are significantly reduced in cortex, but not in cerebellum, of Fmr1 KO mice (D'Hulst et al. 2006). Similar results were obtained for the three subunits conserved in Drosophila (D'Hulst et al. 2006). However, further studies are required to address if this regulation is directly or indirectly mediated by FMRP.

Finally, two recent reports have implicated FMRP as a direct modulator of mRNA turnover. First, FMRP through its $\mathrm{C}$ terminus domain recognizes a G-rich structure in the $3^{\prime} \mathrm{UTR}$ of PSD-95 mRNA and protects it from decay. This effect, observed only in hippocampus and not in cortex, leads to decreased PSD-95 mRNA expression in Fmrl KO animals. Of note, the stabilizing function of FMRP is promoted after the activation of the group I metabotropic glutamate receptors (mGluRs) with the agonist (S)-3,5-dihydroxyphenylglycine (DHPG) (Zalfa et al. 2007). Furthermore, the region-specific effect of FMRP on PSD-95 mRNA stability is consistent with other reports showing that PSD-95 mRNA synaptic translation is affected in cortical synaptoneurosomes of FMRP-lacking mice (Muddashetty et al. 2007; Todd et al. 2003). This leads to the hypothesis that (1) different molecular complexes act, together with FMRP, in cortex and hippocampus; (2) FMRP regulates mRNAs differentially in cell soma and at synapses. Second, in a mouse neuroblastoma cell line, FMRP favors the decay of $N x f 1$ mRNA acting in concert with the nuclear export factor NXF2 (Zhang et al. 2007). Upon NXF2 overexpression, Nxf1 mRNA is rapidly degraded, but this effect is obstructed by silencing FMRP; this would suggest that FMRP mediates the degradation of Nxf1 mRNA induced by NXF2 (Zhang et al. 2007).

Effects of FMRP on mRNA dendritic transport FMRP can also modulate the targeting of mRNAs in subcellular domains far away from the cell body, such as dendrites and spines. While travelling along the dendrites, the mRNAs are thought to be translationally silent; after synaptic stimulation, the mRNPs can be docked to the spines and protein synthesis ensues (Bramham and Wells 2007). FMRP is present along the dendritic shaft, at the basis of the spines (Antar et al. 2004; Feng et al. 1997; Ferrari et al. 2007), in growth cones and mature axons (Antar et al. 2006; Centonze et al. 2008; Price et al. 2006).

The synaptic distribution of FMRP increases upon the activation of the group I mGluRs. In fact, in response to DHPG, the dendritic transport of Fmrl mRNA is enhanced, and FMRP is newly synthesized in close proximity to mGluR5 (Antar et al. 2004; Ferrari et al.
2007; Kao et al. 2010); in addition, FMRP is further recruited by travelling along the microtubules (Antar et al. 2004; Antar et al. 2005; Dictenberg et al. 2008; Ferrari et al. 2007; Kanai et al. 2004). In mammals, FMRP has been reported to interact with the motor proteins kinesin 5 (KIF5) and 3C (Dictenberg et al. 2008; Kanai et al. 2004; Davidovic et al. 2007); in Drosophila, FMRP has been found with kinesin and dynein (Ling et al. 2004). In the model proposed by Dictenberg and colleagues, upon DHPG stimulation, FMRP would interact more efficiently with the kinesin light chain, a major cargo-binding subunit of KIF5, thus promoting the activity-dependent localization of bound mRNAs. Therefore, the stimulus-induced dendritic targeting of some mRNAs such as Map1b, $\alpha$-CaMKII, and Sapap4 is compromised in Fmrl KO hippocampal neurons (Dictenberg et al. 2008). This report is in agreement with previous in vivo studies by Steward and colleagues showing that mRNA transport is not affected in basal condition (Steward et al. 1998).

Recently, a time-lapse imaging study revealed that the dendritic granules containing Fmrl and $\alpha$-CaMKII mRNAs undergo decelerated motion within 0-40 min after DHPG stimulation, likely due to docking of these mRNAs to the spines. Consistently, $\alpha$-CaMKII mRNA distribution in spines increases upon DHPG application to adjacent dendrites. Both effects are abolished in FMRP deficient neurons (Kao et al. 2010). This piece of evidence suggests that FMRP not only contributes to mRNA transport along dendrites, but also to activity-induced docking of the mRNAs in the spines.

Effects of FMRP on protein synthesis In highly polarized cells like neurons, protein synthesis occurs not only in the soma, but also along dendrites, axons, and at synapses. While polyribosomes, translational factors, and specific mRNAs have been detected at post-synaptic sites (Bramham and Wells 2007; Steward and Schuman 2003), considerable evidence indicates regulation of axonal protein synthesis as well (Holt and Bullock 2009). De novo protein synthesis at synapses is a critical event underlying long-lasting forms of synaptic plasticity, required for consolidation and storage of long-term memories. In fact, BDNF-induced Long Term Potentiation (LTP) in hippocampal brain slices can be blocked by translational inhibitors, even when the pre- and post-synapses are severed from the soma (Kang and Schuman 1996). Another form of synaptic plasticity, mGluR-dependent Long Term Depression (mGluR-LTD), also depends on local protein synthesis (Huber et al. 2000).

Remarkably, FMRP is implicated in both basal and activity-dependent local protein synthesis (Hou et al. 2006; Kao et al. 2010; Lu et al. 2004; Muddashetty et al. 2007; Napoli et al. 2008; Park et al. 2008; Zalfa et al. 2003). FMRP represses translation both in vitro (Laggerbauer et al. 
2001; Li et al. 2001) and in vivo (Hou et al. 2006; Lu et al. 2004; Muddashetty et al. 2007; Napoli et al. 2008; Narayanan et al. 2007; Park et al. 2008; Zalfa et al. 2003). The properties of FMRP as translational regulator have been widely investigated through the biochemical fractionation of brain extracts in actively translating ribosomes (polysomes) and translationally silent particles (mRNPs). These studies revealed that more than 200 FMRP target mRNAs display an abnormal polysome/mRNP distribution in lymphoblastoid cells from individuals with FXS, indicative of altered translation (Brown et al. 2001). In the brain from Fmrl KO mice, several mRNAs including $\alpha$-CaMKII, Arc, Map $1 b$ are preferentially distributed on polysomes rather than on mRNPs as result of excessive translation. Accordingly, the levels of the proteins encoded by those mRNAs are significantly increased in the absence of FMRP (Zalfa et al. 2003). In addition, these changes are also present in purified synaptoneurosomes (Muddashetty et al. 2007; Zalfa et al. 2003), extending the function of FMRP as a repressor to synapses. In response to DHPG stimulation, however, FMRP-mediated inhibition of $\alpha$-CaMKII mRNA is rapidly released; this activity-dependent response is abolished in the absence of FMRP (Hou et al. 2006; Kao et al. 2010; Muddashetty et al. 2007). Finally, a high-throughput proteomic study recently showed that the expression of over 100 proteins is altered in synaptoneurosomes isolated from Fmrl KO neurons, possibly due to affected dendritic mRNA localization and protein synthesis (Liao et al. 2008). At the level of the synaptic compartment, local protein synthesis can be coupled with membrane receptors. It has been demonstrated that $\mathrm{DCC}$, the receptor for the axonal guidance factor netrin, anchors components of the translational machinery in growth cones, filopodial tips, and at synapses (Tcherkezian et al. 2010). In addition, FMRP interacts with the sodium-activated potassium channel Slack$\mathrm{B}$ and recruits some co-interacting mRNAs (Maplb and Arc mRNAs) to the channel (Brown et al. 2010). Therefore, it is tempting to hypothesize that FMRP is not only implicated in the regulation of local translation, but also couples it to synaptic membrane receptors.

The complex FMRP regulation downstream receptor activation has been investigated by several laboratories and is summarized in Fig. 1.

FMRP form different $m R N P$ particles The mechanisms responsible for FMRP-dependent protein synthesis are still debated. To investigate this aspect, the polysome/mRNPs sedimentation of protein extracts along sucrose gradients has been used by different laboratories delivering different results (Zalfa et al. 2006). Initial studies from Dreyfuss' laboratory showed that in mammalian cells, FMRP is mainly associated with mRNPs (Siomi et al. 1996). Following studies detected FMRP either co-fractionating with polysomes (Ceman et al. 2003; Khandjian et al. 2004; Stefani et al. 2004) or with mRNPs (Ishizuka et al. 2002; Monzo et al. 2006; Napoli et al. 2008; Papoulas et al. 2010; Siomi et al. 1996; Zalfa et al. 2003) or equally distributed between polysomes and mRNPs (Brown et al. 2001). FMRP can associate with many nuclear and cytoplasmic partners forming different neuronal granules, including $\mathrm{P}$ bodies, stress granules, and transport granules (Anderson and Kedersha 2006; Kanai et al. 2004; Zalfa et al. 2006). This suggests that FMRP can take part in a variety of mRNPs and is possibly influenced by its phosphorylation state (Ceman et al. 2003). Importantly for the physiology of the FMRP complexes, both P bodies and stress granules do not contain large ribosomal subunits and polysomes (Anderson and Kedersha 2006). Furthermore, the distribution of FMRP on both mRNPs and polysomes could account for different functions of FMRP in either repressing or activating translation (Zalfa et al. 2006). In agreement with this hypothesis, Brown and colleagues found that out of 251 mRNAs displaying different polysomal distribution in cells from FXS patients, 136 were increased on polysomes and 115 decreased (Brown et al. 2001), suggesting that FMRP might have a dual role in translation.

\section{The FMRP-CYFIP1-eIF4E complex: regulation of translational initiation}

The hypothesis that FMRP is implicated in the repression of translational initiation is supported by the recent discovery that the Cytoplasmic FMRP Interacting Protein 1 (CYFIP1) acts as an eIF4E-binding protein (Napoli et al. 2008). CYFIP1, also known as Specifically Rac1 Activated protein 1 (SRA-1), was identified early as a partner of FMRP in neurons (Schenck et al. 2003; Schenck et al. 2001). CYFIP1 is also a component of a signaling machinery controlling the actin cytoskeleton, formed by the WASP-family verprolin-homologous (WAVE) (Takenawa and Suetsugu 2007).

As proposed by Napoli et al. (2008), CYFIP1 is a neuronal eIF4E-binding protein (4E-BP). The molecular function of 4E-BPs is to repress mRNA translation by sequestering the cap-binding protein eIF4E. The 4E-BPs and eIF4G, the scaffolding protein required for the assembly of the active initiation complex, share a canonical eIF4E-binding site (YXXXXL $\Phi$, where $\mathrm{X}$ is any amino acid and $\Phi$ is a hydrophobic amino acid) (Costa-Mattioli et al. 2009; Marcotrigiano et al. 1999), therefore competing for the binding to eIF4E. As a consequence, the interaction of the 4E-BPs with eIF4E blocks the translation initiation (Fig. 2).

Three canonical 4E-BPs have been identified in mammals. 4E-BP1 is mostly present in adipose tissues and in pancreas, 


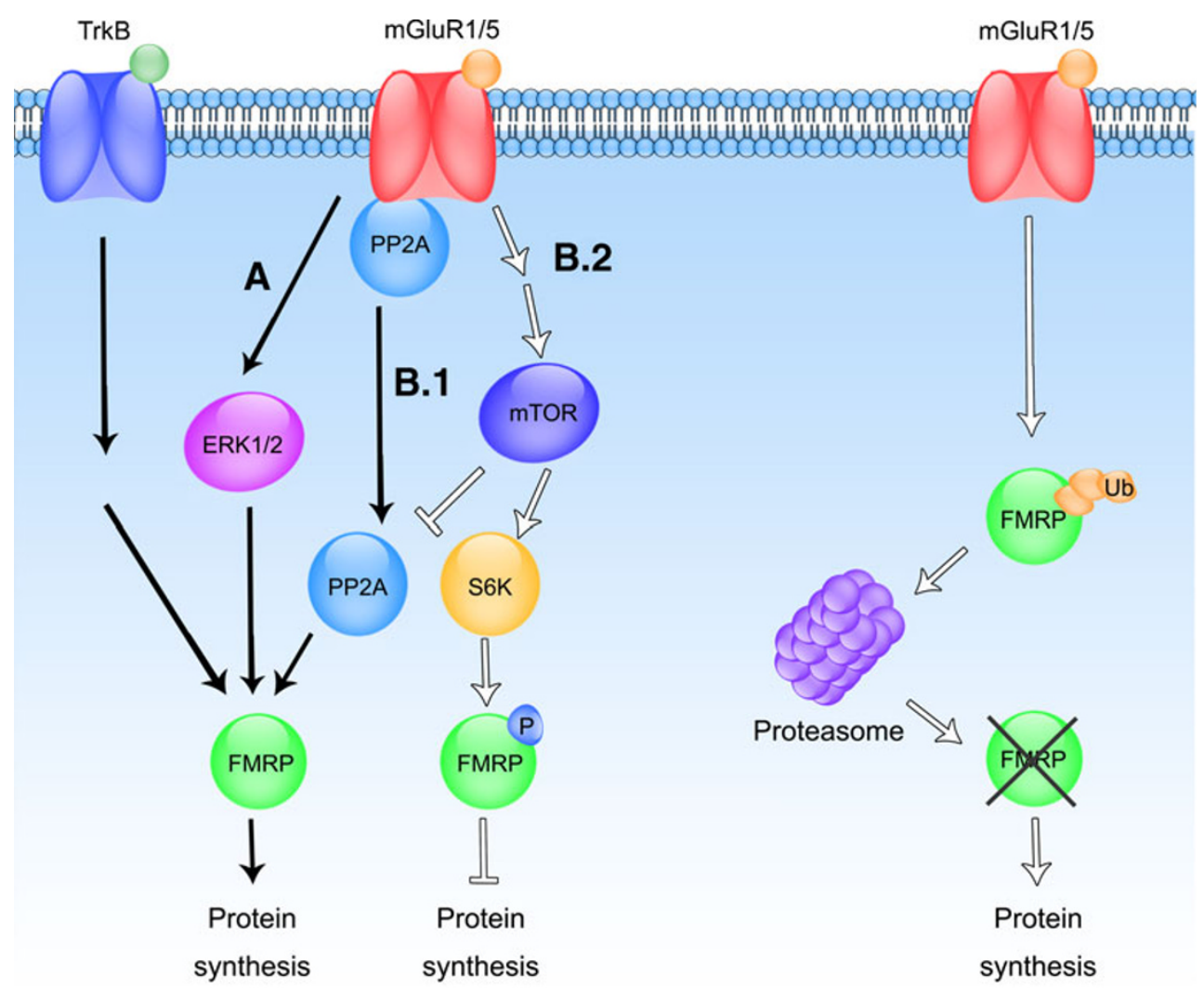

Fig. 1 Model for a postsynaptic FMRP signaling. At synapses, FMRP translational control is released upon TrkB tyrosin kinase signaling activated by BDNF (Napoli et al. 2008) and/or group I mGluRs cascade activated by DHPG (Napoli et al. 2008; Narayanan et al. 2007; Narayanan et al. 2008; Osterweil et al. 2010). Two alternative models have been proposed for the mGluR signaling upstream FMRP. The first one $(A)$ proposes that the kinase ERK1/2 activation releases FMRP translational inhibition (Osterweil et al. 2010). The second one $(B)$ implicates a bimodal PP2A/S6K signaling: an early dephosphorylation by PP2A (B.1) activates translation; sustained DHPG

4E-BP3 in the liver and 4E-BP2 in brain, which expresses little or no 4E-BP1 and 3 (Banko et al. 2005; Klann and Dever 2004). These proteins regulate a large subset of cellular mRNAs. The translation of a small number of specific mRNAs can be regulated by other non-canonical 4E-BPs. Two examples have been so far reported: the Drosophila Cup and the vertebrate Maskin/Neuroguidin. In such cases, the 4E-BP (Maskin or Neuroguidin, Cup) sequesters eIF4E and relies on a specific RNA-binding protein (CPEB, and Bruno, respectively) to inhibit the translation of associated mRNAs (Richter and Klann 2009) (Fig. 2). The CYFIP1-FMRP complex closely resembles these complexes: in brain and at synapses, CYFIP1 tethers the mRNAs associated with FMRP on the eIF4E, thus repressing their translation (Napoli et al. 2008) (Fig. 2). CYFIP1, as well as FMRP and eIF4E, co-fractionates with mRNPs along sucrose gradients from mouse brain lysates. Moreover, CYFIP1 associates with the cap-binding complex in an FMRP-independent manner. Although CYFIP1 does not have a canonical eIF4E- stimulation activates mTOR pathway (B.2), which suppresses PP2A activity and stimulates S6K, thus leading to FMRP phosphorylation and translational block (Narayanan et al. 2007; Narayanan et al. 2008). Furthermore, activation of group I mGluRs induces an early raise of FMRP due to protein synthesis (Antar et al. 2004; Ferrari et al. 2007; Kao et al. 2010) followed by a proteasome-dependent degradation of the protein (Hou et al. 2006; Zhao et al. 2011), restoring normal FMRP levels. Early events are indicated with black arrows, while late events induced by sustained stimulation are indicated by white arrows

binding sequence (YXXXXL $\Phi)$, it directly binds eIF4E. In fact, CYFIP1 possesses a "non canonical" sequence predicted to form a peculiar "reverse L shaped" structure, which overlaps with the region of the 4E-BPs fitting into the eIF4E pocket (Napoli et al. 2008).

The FMRP-CYFIP1-eIF4E complex contains $B C 1$ RNA, as well as several known FMRP target mRNAs, including Map1b, $\alpha$ CaMKII, and App mRNAs. Since BC1 RNA can mediate the association of specific mRNAs to FMRP, loss of $B C 1$ affects, to differing extents, the recruitment of those mRNAs. Consistent with this evidence, the downregulation of CYFIP1 in cultured neurons, as well as its genetic depletion in mouse, causes a significant increase in $\alpha$-CaMKII, MAP1B, and APP protein levels (Napoli et al. 2008).

Remarkably, the inhibitory FMRP-CYFIP1-eIF4E complex is present along dendrites and at synapses, but its formation can be reversed upon neuronal activity (Fig. 3). The stimulation of synaptoneurosomes with either BDNF or DHPG favors the release of eIF4E from CYFIP1, thus 


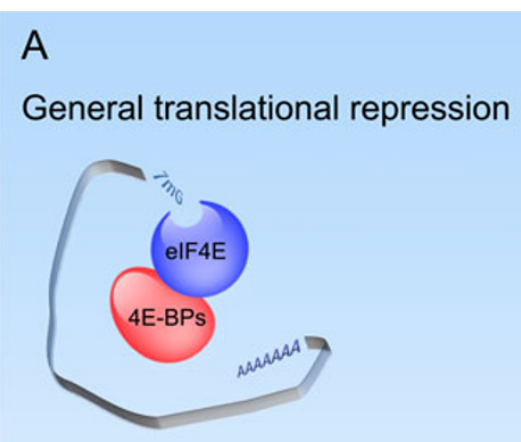

B

C

\section{Specific translational repression}
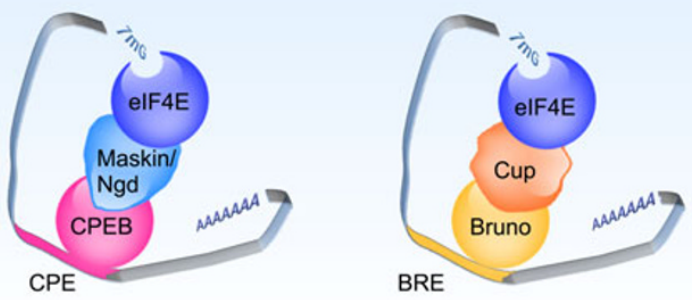

Fig. 2 mRNA translational repression. a General mRNA translation is repressed by binding of 4E-BP1/2/3 (red) to the cap-binding protein eIF4E (blue). b Specific translational regulation through sequence specific regulatory elements. mRNAs harboring the Cytoplasmic Polyadenylation Element (CPE) are recruited by CPEB (purple) and their translation repressed by Maskin/Neuroguidin (light blue); c

alleviating the translational block (Napoli et al. 2008). In conclusion, these data are consistent with a model whereby FMRP tethers specific mRNAs on CYFIP1, which in turn sequesters eIF4E and represses translation initiation. Upon synaptic stimuli, FMRP-CYFIP1 dissociates from eIF4E and translation is activated (Fig. 3).

The mechanisms reverting the CYFIP1-mediated repression are unknown. In several cell types, 4E-BPs are regulated through the extracellular signal-regulated kinase (ERK), phosphoinositide 3-kinase (PI3K) and mammalian target of rapamycin (mTOR) pathways (Fig. 1). Upon an array of stimuli, the activation of the Ser/Thr kinase mTOR leads to the phosphorylation of several targets, including the kinase responsible for FMRP phosphorylation, S6K, and the 4E-BPs. The phosphorylation of the 4E-BPs disrupts the interaction with eIF4E, therefore relieving the translational inhibition (Richter and Klann 2009). Further studies are necessary to determine if CYFIP1 activity can also be modulated by post-translational modifications.

Translational control and Autism Spectrum Disorder As discussed, de novo local protein synthesis is required for synaptic plasticity; in particular, the control of translational
D E

mRNAs carrying the Bruno-Responsive Element (BRE) are bound by Bruno (yellow) and their translation inhibited by Cup (orange). d FMRP (green) can either directly interact with the mRNAs or e recruit them to the inhibitory complex by base-pairing with the non coding RNA $B C 1$. In this case, the translation repression occurs via the eIF4E-BP CYFIP1 (violet)

initiation mediated by mTOR signal cascade and 4E-BPs is critical for the long-lasting changes underlying the consolidation and storage of long-term memories. In fact, both late phase LTP (L-LTP) and mGluR-dependent LTD trigger mTOR activation, resulting in enhanced 4E-BP2 phosphorylation and increased initiation complex formation (CostaMattioli et al. 2009). Additionally, the mTOR inhibitor rapamycin blocks long-lasting changes and memory consolidation in mammals (Costa-Mattioli et al. 2009). Mice lacking 4E-BP2 show impaired hippocampal LTP: early LTP (E-LTP) is converted in late LTP (LTP) and mice present memory deficits in several behavioral tests (Banko et al. 2007; Banko et al. 2005). Likewise, mice lacking FMRP, used as model of FXS, display numerous neurobehavioral defects, including enhanced mGluR-dependent LTD and defective LTP (Hou et al. 2006; Huber et al. 2002; Meredith et al. 2007; Pfeiffer and Huber 2009). According to the so-called mGluR theory, the increased LTD in FMRP deficient mice is due to exaggerated mGluR-dependent translation; when FMRP is lost, uncontrolled protein synthesis would result in excessive AMPA internalization and increased LTD (Bear et al. 2004). A plausible candidate in this process is Arc mRNA, whose de novo synthesis is 
Fig. 3 Regulation of the FMRPCYFIP1-eIF4E complex. FMRP (green) binds the mRNAs in a $B C 1$-dependent or independent manner and anchors them to CYFIP1 (violet). CYFIP1 binds eIF4E (blue), preventing the formation of active translational initiation complexes. Upon synaptic stimuli, i.e., activation of the TrkB (BDNF) or mGluR (DHPG) receptors, CYFIP1 and FMRP are released from eIF4E, which then binds eIF4G allowing protein synthesis to occur

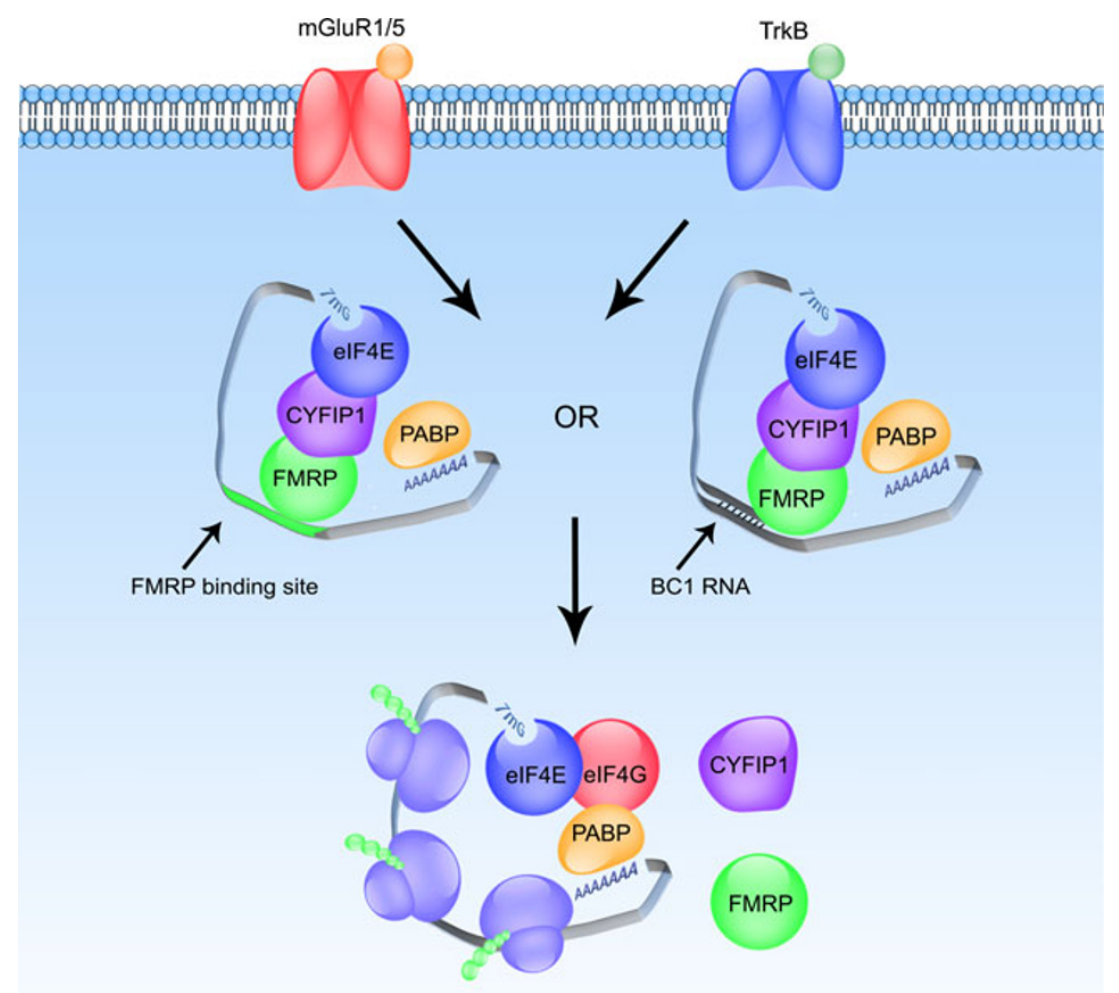

excessive in the absence of FMRP and has been implicated in AMPA receptors trafficking in response to mGluR-LTD (Park et al. 2008; Waung et al. 2008; Zalfa et al. 2003). In support of the mGluR theory, some morphological, physiological, and behavioral features of FXS can be rescued in model organisms either by administration of a mGluR antagonist (MPEP) (McBride et al. 2005; Tucker et al. 2006; Yan et al. 2005) or genetic reduction of mGluR5 (Dolen et al. 2007).

The mTOR pathway could play a role in FXS. First, the fine tuning of the PP2A/S6K activity through the mTOR signaling modulates the phosphorylation state of FMRP (Narayanan et al. 2007; Narayanan et al. 2008) (Fig. 1). Second, elevated activity of mTOR pathway has been found in Fmrl KO mice (Sharma et al. 2010). In FMRP-lacking hippocampi, both mTOR phosphorylation and activity are enhanced, resulting in increased phosphorylation of S6K, 4E-BPs, and consequently eIF4E-eIF4G interaction (Sharma et al. 2010). This evidence further indicates that FMRP is involved in modulating translational initiation.

Genetic manipulation of some components of mTOR signal cascade, such as TSC2, results in synaptic plasticity defects and behavioral anomalies in mice (Ehninger et al. 2008a; Hoeffer et al. 2008). Remarkably, mutations in components of mTOR signaling have been linked to learning disabilities and ASD (Ehninger et al. 2008b).

Likewise, both CYFIP1 and eIF4E, key components for the FMRP-regulated protein synthesis, have been correlated with ASD. CYFIP1 gene is located on a hot spot chromosomal region for ASD, the 15q11-13 chromosome. This region lies within the breakpoints (BP) 1 and 3; it is characterized by a proximal not imprinted region (within BP1 and BP2), a large imprinted region with several paternally imprinted and two maternally imprinted genes, and a distal non-imprinted region. CYFIP1 gene does not undergo imprinting and, together with other three genes, is located in the proximal not imprinted region (BP1-BP2). Altered imprinting of the genes distally to the BP2 can give rise to three ASD-related syndromes, namely the $15 \mathrm{q}$ duplication syndrome, Angelman Syndrome, and PraderWilli Syndrome (Chamberlain and Lalande 2010).

Angelman Syndrome (AS) is due to loss of function of the maternal copy of the imprinted gene $U B E 3 A$. In normal individuals, only the maternally inherited allele is expressed in a brain-specific manner, while the paternal copy is silenced; in patients with $\mathrm{AS}$, the maternal $U B E 3 A$ is not longer expressed. AS is characterized by intellectual disability, deficits in verbal communication, motor dysfunction, ataxic gait, seizures, cognitive impairment, epilepsy, 
behavioral features (excitability, frequent smiling, handflapping movements), and sometimes hyperactivity. On the other hand, loss of expression of the paternal copy of several genes paternally imprinted leads to Prader-Willi Syndrome (PWS). This disease is featured by mild to moderate cognitive deficit, behavioral problems, and hyperphagia leading to morbid obesity.

Of interest, a subgroup of patients with FXS shows a PWSlike phenotype with severe hyperphagia, obesity, short stature, short fingers and toes, and hypogonadism (de Vries et al. 1993; Nowicki et al. 2007). FXS children with Prader-Willi phenotype do not have cytogenetic alterations of 15q11-13 region, but have a significant reduction in CYFIP1 mRNA levels compared to FXS individuals without PWS-like phenotype or unaffected individuals (Nowicki et al. 2007). As mentioned, CYFIP1 lies within the proximal not imprinted gene, which includes three other genes, TUBGPC5, NIPA2, and NIPA1. Large deletions of the 15q11-13 region including these four genes lead to more severe neurobehavioral phenotype in both PWS and AS, underlining the potential role of these genes in ASD (Butler et al. 2004; Sahoo et al. 2006). Furthermore, microdeletions or microduplications of the proximal non-imprinted genes have been found to co-segregate with cognitive disabilities and ASD (Doornbos et al. 2009; Murthy et al. 2007; van der Zwaag et al. 2010). In particular, BP1-BP2 microduplications are associated with developmental delay, mental retardation, speech impairment, and behavioral alterations (ADHD, autism, obsessive-compulsive behavior) (Doornbos et al. 2009; Murthy et al. 2007). These observations, together with the functional linkage of CYFIP1 to FXS, point towards a role of CYFIP1 in behavioral anomalies and ASD. The other key partner of the functional FMRP complex, eIF4E, has been recently implicated in autism as well. Genome-wide association studies in patients with ASD have indicated linkage to a region containing the eIF4E gene on chromosome 4q (Trikalinos et al. 2006; Yonan et al. 2003). Moreover, a de novo translocation involving the chromosomal region containing eIF4E has been found in a boy affected by Autistic Disorder (Neves-Pereira et al. 2009). Moreover, a heterozygous nucleotide insertion in the eIF4E promoter has been detected in two unrelated families with two autistic siblings, likely leading to downregulation of eIF4E (Neves-Pereira et al. 2009).

\section{Future perspectives}

In conclusion, we propose that both CYFIP1 and eIF4E could contribute to the ASD phenotypes observed in FXS. Genetic alterations of the FMRP-CYFIP1-eIF4E complex, as well as other modulators of local protein synthesis, lead to cognitive delay and behavioral disturbances, thus emphasizing that defective local translation may underlie intellectual disability and autism. Although the mRNAs deregulated in the absence of FMRP have been deeply investigated so far, little information is available concerning FMRP-CYFIP1 interactome networks. We believe that future studies should be addressed to define FMRP and CYFIP1-related proteins. In fact, alterations in the proteins co-interacting with FMRP may explain the reduced penetrance of ASD phenotype of FXS. Moreover, since common pathways may be implicated in related neurodevelopmental disorders, these studies may lay the ground work for the study of novel susceptibility genes for ID and ASD.

\section{Acronyms}

$\begin{array}{ll}\text { 4E-BPs } & \text { 4E binding proteins } \\ \text { AS } & \text { Angelman syndrome } \\ \text { ASD } & \text { Autism spectrum disorder } \\ \text { BC1 } & \text { Brain cytoplasmic 1 } \\ \text { BDNF } & \text { Brain derived neurotrophic factor } \\ \text { CYFIP1 } & \text { Cytoplasmic FMRP interacting protein 1 } \\ \text { DHPG } & \text { (S)-3,5-dihydroxyphenylglycine } \\ \text { eIF4E } & \text { Eukaryotic initiation factor 4E } \\ \text { eIF4G } & \text { Eukaryotic initiation factor 4 G } \\ \text { ERK } & \text { Extracellular signal-regulated kinases } \\ \text { FMR1 } & \text { Fragile X mental retardation 1 } \\ \text { FMRP } & \text { Fragile X mental retardation protein } \\ \text { FX-POI } & \text { Fragile X-associated primary ovarian } \\ & \text { insufficiency } \\ \text { FXS } & \text { Fragile X syndrome } \\ \text { FXTAS } & \text { Fragile X-associated tremor/ataxia syndrome } \\ \text { LTD } & \text { Long-term depression } \\ \text { LTP } & \text { Long-term potentiation } \\ \text { mGluRs } & \text { Metabotropic glutamate receptors } \\ \text { mRNP } & \text { Messenger ribonucleoparticle } \\ \text { mTOR } & \text { Mammalian target of rapamycin } \\ \text { PP2A } & \text { Protein phosphatase 2A } \\ \text { PWS } & \text { Prader-Willi syndrome } \\ \text { RBP } & \text { RNA binding protein } \\ \text { S6K } & \text { Ribosomal protein S6 kinase } \\ \text { TSC2 } & \text { Tuberous Sclerosis protein 2 } \\ & \end{array}$

Acknowledgments Silvia De Rubeis was partially supported by the Associazione Italiana Sindrome X Fragile (http://www.xfragile.net). This work was supported by grants from Telethon, COFIN, FWO and VIB. We thank Bart De Strooper for providing us support through the Methusalem grant. We thank Elien Theuns and Eliane Cherretté for assistance. We are very grateful to Cornelia de Moor for helpful discussions and critical reading of the manuscript.

Open Access This article is distributed under the terms of the Creative Commons Attribution Noncommercial License which permits any noncommercial use, distribution, and reproduction in any medium, provided the original author(s) and source are credited. 


\section{References}

Abrahams BS, Geschwind DH. Advances in autism genetics: on the threshold of a new neurobiology. Nat Rev Genet. 2008;9:341-55.

Allen EG, He W, Yadav-Shah M, Sherman SL. A study of the distributional characteristics of FMR1 transcript levels in 238 individuals. Hum Genet. 2004;114:439-47.

Anderson P, Kedersha N. RNA granules. J Cell Biol. 2006;172:803-8.

Antar LN, Afroz R, Dictenberg JB, Carroll RC, Bassell GJ. Metabotropic glutamate receptor activation regulates fragile $\mathrm{x}$ mental retardation protein and FMR1 mRNA localization differentially in dendrites and at synapses. J Neurosci. 2004;24:2648-55.

Antar LN, Dictenberg JB, Plociniak M, Afroz R, Bassell GJ. Localization of FMRP-associated mRNA granules and requirement of microtubules for activity-dependent trafficking in hippocampal neurons. Genes Brain Behav. 2005;4:350-9.

Antar LN, Li C, Zhang H, Carroll RC, Bassell GJ. Local functions for FMRP in axon growth cone motility and activity-dependent regulation of filopodia and spine synapses. Mol Cell Neurosci. 2006;32:37-48.

Bagni C, Greenough WT. From mRNP trafficking to spine dysmorphogenesis: the roots of fragile X syndrome. Nat Rev Neurosci. 2005;6:376-87.

Banko JL, Poulin F, Hou L, DeMaria CT, Sonenberg N, Klann E. The translation repressor $4 \mathrm{E}-\mathrm{BP} 2$ is critical for eIF4F complex formation, synaptic plasticity, and memory in the hippocampus. J Neurosci. 2005;25:9581-90.

Banko JL, Merhav M, Stern E, Sonenberg N, Rosenblum K, Klann E. Behavioral alterations in mice lacking the translation repressor 4E-BP2. Neurobiol Learn Mem. 2007;87:248-56.

Bassell GJ, Warren ST. Fragile X syndrome: loss of local mRNA regulation alters synaptic development and function. Neuron. 2008;60:201-14.

Bear MF, Huber KM, Warren ST. The mGluR theory of fragile X mental retardation. Trends Neurosci. 2004;27:370-7.

Belmonte MK, Bourgeron T. Fragile X syndrome and autism at the intersection of genetic and neural networks. Nat Neurosci. 2006;9:1221-5.

Berman RF, Willemsen R. Mouse models of fragile $\mathrm{x}$-associated tremor ataxia. J Investig Med. 2009;57:837-41.

Berry-Kravis E. Epilepsy in fragile X syndrome. Dev Med Child Neurol. 2002;44:724-8.

Bramham CR, Wells DG. Dendritic mRNA: transport, translation and function. Nat Rev Neurosci. 2007;8:776-89.

Bregman JD, Leckman JF, Ort SI. Thyroid function in fragile-X syndrome males. Yale J Biol Med. 1990;63:293-9.

Brouwer JR, Huizer K, Severijnen LA, Hukema RK, Berman RF, Oostra BA, et al. CGG-repeat length and neuropathological and molecular correlates in a mouse model for fragile Xassociated tremor/ataxia syndrome. J Neurochem. 2008;107:167182.

Brouwer JR, Willemsen R, Oostra BA. The FMR1 gene and fragile $\mathrm{X}$-associated tremor/ataxia syndrome. Am J Med Genet B Neuropsychiatr Genet. 2009;150B:782-98.

Brown V, Jin P, Ceman S, Darnell JC, O'Donnell WT, Tenenbaum SA, et al. Microarray identification of FMRP-associated brain mRNAs and altered mRNA translational profiles in fragile $\mathrm{X}$ syndrome. Cell. 2001;107:477-87.

Brown MR, Kronengold J, Gazula VR, Chen Y, Strumbos JG, Sigworth FJ, et al. Fragile X mental retardation protein controls gating of the sodium-activated potassium channel Slack. Nat Neurosci. 2010;13:819-21.

Butler MG, Bittel DC, Kibiryeva N, Talebizadeh Z, Thompson T. Behavioral differences among subjects with Prader-Willi syn- drome and type I or type II deletion and maternal disomy. Pediatrics. 2004;113:565-73.

Ceman S, O’Donnell WT, Reed M, Patton S, Pohl J, Warren ST. Phosphorylation influences the translation state of FMRPassociated polyribosomes. Hum Mol Genet. 2003;12:3295305.

Centonze D, Rossi S, Mercaldo V, Napoli I, Ciotti MT, De Chiara V, et al. Abnormal striatal GABA transmission in the mouse model for the fragile X syndrome. Biol Psychiatry. 2008;63: 963-73.

Chamberlain SJ, Lalande M. Neurodevelopmental disorders involving genomic imprinting at human chromosome 15q11-q13. Neurobiol Dis. 2010;39:13-20.

Costa-Mattioli M, Sossin WS, Klann E, Sonenberg N. Translational control of long-lasting synaptic plasticity and memory. Neuron. 2009;61:10-26.

Cruz-Martin A, Crespo M, Portera-Cailliau C. Delayed stabilization of dendritic spines in fragile $X$ mice. J Neurosci. 2010;30: 7793-803.

Davidovic L, Jaglin XH, Lepagnol-Bestel AM, Tremblay S, Simonneau M, Bardoni B, Khandjian EW. The fragile X mental retardation protein is a molecular adaptor between the neurospecific KIF3C kinesin and dendritic RNA granules. Hum Mol Genet. 2007; 16:3047-58.

D'Hulst C, De Geest N, Reeve SP, Van Dam D, De Deyn PP, Hassan $\mathrm{BA}$, et al. Decreased expression of the GABAA receptor in fragile X syndrome. Brain Res. 2006;1121:238-45.

De Boulle K, Verkerk AJ, Reyniers E, Vits L, Hendrickx J, Van Roy B, et al. A point mutation in the FMR-1 gene associated with fragile X mental retardation. Nat Genet. 1993;3:31-5.

De Rubeis S, Bagni C. Fragile X mental retardation protein control of neuronal mRNA metabolism: insights into mRNA stability. Mol Cell Neurosci. 2010;43:43-50.

de Vries BB, Fryns JP, Butler MG, Canziani F, Wesby-van Swaay E, van Hemel JO, et al. Clinical and molecular studies in fragile $\mathrm{X}$ patients with a Prader-Willi-like phenotype. J Med Genet. 1993;30:761-6.

Dictenberg JB, Swanger SA, Antar LN, Singer RH, Bassell GJ. A direct role for FMRP in activity-dependent dendritic mRNA transport links filopodial-spine morphogenesis to fragile $\mathrm{X}$ syndrome. Dev Cell. 2008;14:926-39.

Dolen G, Osterweil E, Rao BS, Smith GB, Auerbach BD, Chattarji S, et al. Correction of fragile $\mathrm{X}$ syndrome in mice. Neuron. 2007;56:955-62.

Doornbos M, Sikkema-Raddatz B, Ruijvenkamp CA, Dijkhuizen T, Bijlsma EK, Gijsbers AC, et al. Nine patients with a microdeletion $15 \mathrm{q} 11.2$ between breakpoints 1 and 2 of the Prader-Willi critical region, possibly associated with behavioural disturbances. Eur J Med Genet. 2009;52:108-15.

Edbauer D, Neilson JR, Foster KA, Wang CF, Seeburg DP, Batterton $\mathrm{MN}$, et al. Regulation of synaptic structure and function by FMRP-associated microRNAs miR-125b and miR-132. Neuron. 2010;65:373-84.

Ehninger D, Han S, Shilyansky C, Zhou Y, Li W, Kwiatkowski DJ, et al. Reversal of learning deficits in a Tsc2+/- mouse model of tuberous sclerosis. Nat Med. 2008a;14:843-8.

Ehninger D, Li W, Fox K, Stryker MP, Silva AJ. Reversing neurodevelopmental disorders in adults. Neuron. 2008b;60: 950-60.

Entezam A, Biacsi R, Orrison B, Saha T, Hoffman GE, Grabczyk E, et al. Regional FMRP deficits and large repeat expansions into the full mutation range in a new Fragile $\mathrm{X}$ premutation mouse model. Gene. 2007;395:125-34.

Feng Y, Zhang F, Lokey LK, Chastain JL, Lakkis L, Eberhart D, et al. Translational suppression by trinucleotide repeat expansion at FMR1. Science. 1995;268:731-4. 
Feng Y, Absher D, Eberhart DE, Brown V, Malter HE, Warren ST. FMRP associates with polyribosomes as an mRNP, and the I304N mutation of severe fragile $\mathrm{X}$ syndrome abolishes this association. Mol Cell. 1997;1:109-18.

Ferrari F, Mercaldo V, Piccoli G, Sala C, Cannata S, Achsel T, et al. The fragile $\mathrm{X}$ mental retardation protein-RNP granules show an mGluR-dependent localization in the post-synaptic spines. Mol Cell Neurosci. 2007;34:343-54.

Fombonne E. Epidemiology of autistic disorder and other pervasive developmental disorders. J Clin Psychiatry. 2005;66 Suppl 10:3-8.

Gabus C, Mazroui R, Tremblay S, Khandjian EW, Darlix JL. The fragile $\mathrm{X}$ mental retardation protein has nucleic acid chaperone properties. Nucleic Acids Res. 2004;32:2129-37.

Gantois I, Vandesompele J, Speleman F, Reyniers E, D'Hooge R, Severijnen LA, et al. Expression profiling suggests underexpression of the GABA(A) receptor subunit delta in the fragile $\mathrm{X}$ knockout mouse model. Neurobiol Dis. 2006;21:346-57.

Garcia-Arocena D, Hagerman PJ. Advances in understanding the molecular basis of FXTAS. Hum Mol Genet. 2010;19:R83-9.

Garcia-Nonell C, Ratera ER, Harris S, Hessl D, Ono MY, Tartaglia N, et al. Secondary medical diagnosis in fragile $\mathrm{X}$ syndrome with and without autism spectrum disorder. Am J Med Genet A. 2008;146A:1911-6.

Gedeon AK, Baker E, Robinson H, Partington MW, Gross B, Manca A, et al. Fragile $\mathrm{X}$ syndrome without $\mathrm{CCG}$ amplification has an FMR1 deletion. Nat Genet. 1992;1:341-4.

Geschwind DH, Levitt P. Autism spectrum disorders: developmental disconnection syndromes. Curr Opin Neurobiol. 2007;17:103-11.

Greco CM, Hagerman RJ, Tassone F, Chudley AE, Del Bigio MR, Jacquemont $\mathrm{S}$, et al. Neuronal intranuclear inclusions in a new cerebellar tremor/ataxia syndrome among fragile $\mathrm{X}$ carriers. Brain. 2002;125:1760-71.

Greco CM, Berman RF, Martin RM, Tassone F, Schwartz PH, Chang A, et al. Neuropathology of fragile X-associated tremor/ataxia syndrome (FXTAS). Brain. 2006;129:243-55.

Hagerman RJ, Hagerman PJ. The fragile X premutation: into the phenotypic fold. Curr Opin Genet Dev. 2002;12:278-83.

Hagerman RJ, Leavitt BR, Farzin F, Jacquemont S, Greco CM, Brunberg JA, et al. Fragile-X-associated tremor/ataxia syndrome (FXTAS) in females with the FMR1 premutation. Am J Hum Genet. 2004;74:1051-6.

Hallahan BP, Craig MC, Toal F, Daly EM, Moore CJ, Ambikapathy A, Robertson D, Murphy KC, Murphy DG. In vivo brain anatomy of adult males with Fragile $\mathrm{X}$ syndrome: an MRI study. Neuroimage. 2011;54:16-24.

Harris SW, Hessl D, Goodlin-Jones B, Ferranti J, Bacalman S, Barbato I, et al. Autism profiles of males with fragile X syndrome. Am J Ment Retard. 2008;113:427-38.

Hatton DD, Sideris J, Skinner M, Mankowski J, Bailey Jr DB, Roberts $\mathrm{J}$, et al. Autistic behavior in children with fragile $\mathrm{X}$ syndrome: prevalence, stability, and the impact of FMRP. Am J Med Genet A. 2006;140A:1804-13

Hernandez RN, Feinberg RL, Vaurio R, Passanante NM, Thompson $\mathrm{RE}$, Kaufmann WE. Autism spectrum disorder in fragile $\mathrm{X}$ syndrome: a longitudinal evaluation. Am J Med Genet A. 2009;149A:1125-37.

Hoeffer CA, Tang W, Wong H, Santillan A, Patterson RJ, Martinez LA, et al. Removal of FKBP12 enhances mTOR-Raptor interactions, LTP, memory, and perseverative/repetitive behavior. Neuron. 2008;60:832-45.

Holt CE, Bullock SL. Subcellular mRNA localization in animal cells and why it matters. Science. 2009;326:1212-6.

Hou L, Antion MD, Hu D, Spencer CM, Paylor R, Klann E. Dynamic translational and proteasomal regulation of fragile $\mathrm{X}$ mental retardation protein controls mGluR-dependent long-term depression. Neuron. 2006;51:441-54.
Huber KM, Kayser MS, Bear MF. Role for rapid dendritic protein synthesis in hippocampal mGluR-dependent long-term depression. Science. 2000;288:1254-7.

Huber KM, Gallagher SM, Warren ST, Bear MF. Altered synaptic plasticity in a mouse model of fragile $\mathrm{X}$ mental retardation. Proc Natl Acad Sci U S A. 2002;99:7746-50.

Irwin SA, Patel B, Idupulapati M, Harris JB, Crisostomo RA, Larsen $\mathrm{BP}$, et al. Abnormal dendritic spine characteristics in the temporal and visual cortices of patients with fragile-X syndrome: a quantitative examination. Am J Med Genet. 2001;98:161-7.

Ishizuka A, Siomi MC, Siomi H. A Drosophila fragile X protein interacts with components of RNAi and ribosomal proteins. Genes Dev. 2002;16:2497-508.

Jacquemont S, Hagerman RJ, Hagerman PJ, Leehey MA. Fragile-X syndrome and fragile $\mathrm{X}$-associated tremor/ataxia syndrome: two faces of FMR1. Lancet Neurol. 2007;6:45-55.

Jin P, Duan R, Qurashi A, Qin Y, Tian D, Rosser TC, et al. Pur alpha binds to rCGG repeats and modulates repeat-mediated neurodegeneration in a Drosophila model of fragile X tremor/ataxia syndrome. Neuron. 2007;55:556-64.

Johnson EM, Kinoshita Y, Weinreb DB, Wortman MJ, Simon R, Khalili K, et al. Role of Pur alpha in targeting mRNA to sites of translation in hippocampal neuronal dendrites. J Neurosci Res. 2006;83:929-43.

Kanai Y, Dohmae N, Hirokawa N. Kinesin transports RNA: isolation and characterization of an RNA-transporting granule. Neuron. 2004;43:513-25.

Kang H, Schuman EM. A requirement for local protein synthesis in neurotrophin-induced hippocampal synaptic plasticity. Science. 1996;273:1402-6.

Kao DI, Aldridge GM, Weiler IJ, Greenough WT. Altered mRNA transport, docking, and protein translation in neurons lacking fragile X mental retardation protein. Proc Natl Acad Sci U S A. 2010;107:15601-6.

Kenneson A, Zhang F, Hagedorn CH, Warren ST. Reduced FMRP and increased FMR1 transcription is proportionally associated with CGG repeat number in intermediate-length and premutation carriers. Hum Mol Genet. 2001;10:1449-54.

Khandjian EW, Huot ME, Tremblay S, Davidovic L, Mazroui R, Bardoni B. Biochemical evidence for the association of fragile X mental retardation protein with brain polyribosomal ribonucleoparticles. Proc Natl Acad Sci U S A. 2004;101:1335762.

Klann E, Dever TE. Biochemical mechanisms for translational regulation in synaptic plasticity. Nat Rev Neurosci. 2004;5: 931-42.

Laggerbauer B, Ostareck D, Keidel EM, Ostareck-Lederer A, Fischer $\mathrm{U}$. Evidence that fragile $\mathrm{X}$ mental retardation protein is a negative regulator of translation. Hum Mol Genet. 2001;10: 329-38.

Lee EK, Kim HH, Kuwano Y, Abdelmohsen K, Srikantan S, Subaran SS, Gleichmann M, Mughal MR, Martindale JL, Yang X, et al. hnRNP C promotes APP translation by competing with FMRP for APP mRNA recruitment to P bodies. Nat Struct Mol Biol. 2010;17:732-39.

Li Z, Zhang Y, Ku L, Wilkinson KD, Warren ST, Feng Y. The fragile X mental retardation protein inhibits translation via interacting with mRNA. Nucleic Acids Res. 2001;29:2276-83.

Liao L, Park SK, Xu T, Vanderklish P, Yates 3rd JR. Quantitative proteomic analysis of primary neurons reveals diverse changes in synaptic protein content in fmrl knockout mice. Proc Natl Acad Sci U S A. 2008;105:15281-6.

Ling SC, Fahrner PS, Greenough WT, Gelfand VI. Transport of drosophila fragile $\mathrm{X}$ mental retardation protein-containing ribonucleoprotein granules by kinesin-1 and cytoplasmic dynein. Proc Natl Acad Sci USA. 2004;101:17428-33. 
Lu R, Wang H, Liang Z, Ku L, O’Donnell WT, Li W, et al. The fragile $\mathrm{X}$ protein controls microtubule-associated protein $1 \mathrm{~B}$ translation and microtubule stability in brain neuron development. Proc Natl Acad Sci U S A. 2004;101:15201-6.

Marcotrigiano J, Gingras AC, Sonenberg N, Burley SK. Capdependent translation initiation in eukaryotes is regulated by a molecular mimic of eIF4G. Mol Cell. 1999;3:707-16.

McBride SM, Choi CH, Wang Y, Liebelt D, Braunstein E, Ferreiro D, et al. Pharmacological rescue of synaptic plasticity, courtship behavior, and mushroom body defects in a Drosophila model of fragile X syndrome. Neuron. 2005;45:753-64.

Meijer H, de Graaff E, Merckx DM, Jongbloed RJ, de Die-Smulders $\mathrm{CE}$, Engelen JJ, et al. A deletion of $1.6 \mathrm{~kb}$ proximal to the CGG repeat of the FMR1 gene causes the clinical phenotype of the fragile X syndrome. Hum Mol Genet. 1994;3:615-20.

Meredith RM, Holmgren CD, Weidum M, Burnashev N, Mansvelder HD. Increased threshold for spike-timing-dependent plasticity is caused by unreliable calcium signaling in mice lacking fragile $\mathrm{X}$ gene FMR1. Neuron. 2007;54:627-38.

Mila M, Castellvi-Bel S, Sanchez A, Barcelo A, Badenas C, Mallolas $\mathrm{J}$, et al. Rare variants in the promoter of the fragile X syndrome gene (FMR1). Mol Cell Probes. 2000;14:115-9.

Miyashiro KY, Beckel-Mitchener A, Purk TP, Becker KG, Barret T, Liu L, et al. RNA cargoes associating with FMRP reveal deficits in cellular functioning in Fmr1 null mice. Neuron. 2003;37: 417-31.

Monzo K, Papoulas O, Cantin GT, Wang Y, Yates 3rd JR, Sisson JC. Fragile $\mathrm{X}$ mental retardation protein controls trailer hitch expression and cleavage furrow formation in Drosophila embryos. Proc Natl Acad Sci U S A. 2006;103:18160-5.

Moss J, Howlin P. Autism spectrum disorders in genetic syndromes: implications for diagnosis, intervention and understanding the wider autism spectrum disorder population. J Intellect Disabil Res. 2009;53:852-73.

Muddashetty RS, Kelic S, Gross C, Xu M, Bassell GJ. Dysregulated metabotropic glutamate receptor-dependent translation of AMPA receptor and postsynaptic density-95 mRNAs at synapses in a mouse model of fragile X syndrome. J Neurosci. 2007;27: 5338-48.

Murthy SK, Nygren AO, El Shakankiry HM, Schouten JP, Al Khayat AI, Ridha A, et al. Detection of a novel familial deletion of four genes between BP1 and BP2 of the Prader-Willi/Angelman syndrome critical region by oligo-array $\mathrm{CGH}$ in a child with neurological disorder and speech impairment. Cytogenet Genome Res. 2007;116:135-40.

Napoli I, Mercaldo V, Boyl PP, Eleuteri B, Zalfa F, De Rubeis S, et al. The fragile $\mathrm{X}$ syndrome protein represses activity-dependent translation through CYFIP1, a new 4E-BP. Cell. 2008;134: 1042-54.

Narayanan U, Nalavadi V, Nakamoto M, Pallas DC, Ceman S, Bassell GJ, et al. FMRP phosphorylation reveals an immediate-early signaling pathway triggered by group I mGluR and mediated by PP2A. J Neurosci. 2007;27:14349-57.

Narayanan U, Nalavadi V, Nakamoto M, Thomas G, Ceman S, Bassell GJ, et al. S6K1 phosphorylates and regulates fragile X mental retardation protein (FMRP) with the neuronal protein synthesisdependent mammalian target of rapamycin (mTOR) signaling cascade. J Biol Chem. 2008;283:18478-82.

Neves-Pereira M, Muller B, Massie D, Williams JH, O’Brien PC, Hughes A, et al. Deregulation of EIF4E: a novel mechanism for autism. J Med Genet. 2009;46:759-65.

Nowicki ST, Tassone F, Ono MY, Ferranti J, Croquette MF, GoodlinJones B, et al. The Prader-Willi phenotype of fragile X syndrome. J Dev Behav Pediatr. 2007;28:133-8.

Osterweil EK, Krueger DD, Reinhold K, Bear MF. Hypersensitivity to mGluR5 and ERK1/2 leads to excessive protein synthesis in the hippocampus of a mouse model of fragile $\mathrm{X}$ syndrome. $\mathrm{J}$ Neurosci. 2010;30:15616-27.

Papoulas O, Monzo KF, Cantin GT, Ruse C, Yates 3rd JR, Ryu YH, et al. dFMRP and Caprin, translational regulators of synaptic plasticity, control the cell cycle at the Drosophila mid-blastula transition. Development. 2010;137:4201-9.

Park S, Park JM, Kim S, Kim JA, Shepherd JD, Smith-Hicks CL, et al. Elongation factor 2 and fragile $\mathrm{X}$ mental retardation protein control the dynamic translation of Arc/Arg3.1 essential for mGluR-LTD. Neuron. 2008;59:70-83.

Pfeiffer BE, Huber KM. The state of synapses in fragile X syndrome. Neuroscientist. 2009;15:549-67.

Price TJ, Flores CM, Cervero F, Hargreaves KM. The RNA binding and transport proteins staufen and fragile $\mathrm{X}$ mental retardation protein are expressed by rat primary afferent neurons and localize to peripheral and central axons. Neuroscience. 2006;141:2107-16.

Primerano B, Tassone F, Hagerman RJ, Hagerman P, Amaldi F, Bagni C. Reduced FMR1 mRNA translation efficiency in fragile $X$ patients with premutations. RNA. 2002;8:1482-8.

Reiss AL, Abrams MT, Greenlaw R, Freund L, Denckla MB. Neurodevelopmental effects of the FMR-1 full mutation in humans. Nat Med. 1995;1:159-67.

Richter JD, Klann E. Making synaptic plasticity and memory last: mechanisms of translational regulation. Genes Dev. 2009;23:1-11.

Sahoo T, Peters SU, Madduri NS, Glaze DG, German JR, Bird LM, et al. Microarray based comparative genomic hybridization testing in deletion bearing patients with Angelman syndrome: genotypephenotype correlations. J Med Genet. 2006;43:512-6.

Schenck A, Bardoni B, Moro A, Bagni C, Mandel JL. A highly conserved protein family interacting with the fragile $\mathrm{X}$ mental retardation protein (FMRP) and displaying selective interactions with FMRP-related proteins FXR1P and FXR2P. Proc Natl Acad Sci U S A. 2001;98:8844-9.

Schenck A, Bardoni B, Langmann C, Harden N, Mandel JL, Giangrande A. CYFIP/Sra-1 controls neuronal connectivity in Drosophila and links the Rac1 GTPase pathway to the fragile X protein. Neuron. 2003;38:887-98.

Sharma A, Hoeffer CA, Takayasu Y, Miyawaki T, McBride SM, Klann $\mathrm{E}$, et al. Dysregulation of mTOR signaling in fragile $\mathrm{X}$ syndrome. J Neurosci. 2010;30:694-702.

Siomi MC, Zhang Y, Siomi H, Dreyfuss G. Specific sequences in the fragile X syndrome protein FMR1 and the FXR proteins mediate their binding to $60 \mathrm{~S}$ ribosomal subunits and the interactions among them. Mol Cell Biol. 1996;16:3825-32.

Slegtenhorst-Eegdeman KE, de Rooij DG, Verhoef-Post M, van de Kant HJ, Bakker CE, Oostra BA, et al. Macroorchidism in FMR1 knockout mice is caused by increased Sertoli cell proliferation during testicular development. Endocrinology. 1998;139:15662.

Sofola OA, Jin P, Qin Y, Duan R, Liu H, de Haro M, et al. RNAbinding proteins hnRNPA2/B1 and CUGBP1 suppress fragile $\mathrm{X}$ CGG premutation repeat-induced neurodegeneration in a Drosophila model of FXTAS. Neuron. 2007;55:565-71.

Stefani G, Fraser CE, Darnell JC, Darnell RB. Fragile X mental retardation protein is associated with translating polyribosomes in neuronal cells. J Neurosci. 2004;24:7272-6.

Steward O, Schuman EM. Compartmentalized synthesis and degradation of proteins in neurons. Neuron. 2003;40:347-59.

Steward O, Bakker CE, Willems PJ, Oostra BA. No evidence for disruption of normal patterns of mRNA localization in dendrites or dendritic transport of recently synthesized mRNA in FMR1 knockout mice, a model for human fragile-X mental retardation syndrome. Neuroreport. 1998;9:477-81.

Takenawa T, Suetsugu S. The WASP-WAVE protein network: connecting the membrane to the cytoskeleton. Nat Rev Mol Cell Biol. 2007;8:37-48. 
Tamanini F, Willemsen R, van Unen L, Bontekoe C, Galjaard H, Oostra BA, et al. Differential expression of FMR1, FXR1 and FXR2 proteins in human brain and testis. Hum Mol Genet. 1997;6:1315-22.

Tan H, Li H, Jin P. RNA-mediated pathogenesis in fragile X-associated disorders. Neurosci Lett. 2009;466:103-8.

Tassone F, Hagerman RJ, Taylor AK, Gane LW, Godfrey TE, Hagerman PJ. Elevated levels of FMR1 mRNA in carrier males: a new mechanism of involvement in the fragile- $X$ syndrome. Am J Hum Genet. 2000;66:6-15.

Tassone F, Iwahashi C, Hagerman PJ. FMR1 RNA within the intranuclear inclusions of fragile $\mathrm{X}$-associated tremor/ataxia syndrome (FXTAS). RNA Biol. 2004;1:103-5.

Tassone F, Beilina A, Carosi C, Albertosi S, Bagni C, Li L, et al. Elevated FMR1 mRNA in premutation carriers is due to increased transcription. RNA. 2007;13:555-62.

Tassone F, De Rubeis S, Carosi C, La Fata G, Serpa G, Raske C, Willemsen R, Hagerman PJ, Bagni C. Differential usage of transcriptional start sites and polyadenylation sites in FMR1 premutation alleles. Nucleic. Acids Res. 2011;PMID: 21478165.

Tcherkezian J, Brittis PA, Thomas F, Roux PP, Flanagan JG. Transmembrane receptor DCC associates with protein synthesis machinery and regulates translation. Cell. 2010;141:632-44.

Todd PK, Mack KJ, Malter JS. The fragile X mental retardation protein is required for type-I metabotropic glutamate receptordependent translation of PSD-95. Proc Natl Acad Sci U S A. 2003; 100:14374-8.

Trikalinos TA, Karvouni A, Zintzaras E, Ylisaukko-oja T, Peltonen L, Jarvela I, et al. A heterogeneity-based genome search meta-analysis for autism-spectrum disorders. Mol Psychiatry. 2006;11:29-36.

Tucker B, Richards RI, Lardelli M. Contribution of mGluR and Fmr1 functional pathways to neurite morphogenesis, craniofacial development and fragile $\mathrm{X}$ syndrome. Hum Mol Genet. 2006;15:3446-58

van der Zwaag B, Staal WG, Hochstenbach R, Poot M, Spierenburg HA, de Jonge MV, et al. A co-segregating microduplication of chromosome $15 \mathrm{q} 11.2$ pinpoints two risk genes for autism spectrum disorder. Am J Med Genet B Neuropsychiatr Genet. 2010;153B:960-6.

Waung MW, Pfeiffer BE, Nosyreva ED, Ronesi JA, Huber KM. Rapid translation of Arc/Arg3.1 selectively mediates mGluR-dependent
LTD through persistent increases in AMPAR endocytosis rate. Neuron. 2008;59:84-97.

Westmark CJ, Malter JS. FMRP mediates mGluR5-dependent translation of amyloid precursor protein. PLoS Biol. 2007;5:e52.

Wohrle D, Kotzot D, Hirst MC, Manca A, Korn B, Schmidt A, et al. A microdeletion of less than $250 \mathrm{~kb}$, including the proximal part of the FMR-I gene and the fragile-X site, in a male with the clinical phenotype of fragile-X syndrome. Am J Hum Genet. 1992;51:299-306.

Yan QJ, Rammal M, Tranfaglia M, Bauchwitz RP. Suppression of two major Fragile $\mathrm{X}$ Syndrome mouse model phenotypes by the mGluR5 antagonist MPEP. Neuropharmacology. 2005;49: 1053-66.

Yonan AL, Alarcon M, Cheng R, Magnusson PK, Spence SJ, Palmer AA, et al. A genomewide screen of 345 families for autismsusceptibility loci. Am J Hum Genet. 2003;73:886-97.

Zalfa F, Bagni C. Another view of the role of FMRP in translational regulation. Cell Mol Life Sci. 2005;62:251-2.

Zalfa F, Giorgi M, Primerano B, Moro A, Di Penta A, Reis S, et al. The fragile $\mathrm{X}$ syndrome protein FMRP associates with BC1 RNA and regulates the translation of specific mRNAs at synapses. Cell. 2003;112:317-27.

Zalfa F, Adinolfi S, Napoli I, Kuhn-Holsken E, Urlaub H, Achsel T, et al. Fragile $\mathrm{X}$ mental retardation protein (FMRP) binds specifically to the brain cytoplasmic RNAs $\mathrm{BC} 1 / \mathrm{BC} 200$ via a novel RNA-binding motif. J Biol Chem. 2005;280:33403-10.

Zalfa F, Achsel T, Bagni C. mRNPs, polysomes or granules: FMRP in neuronal protein synthesis. Curr Opin Neurobiol. 2006;16:265-9.

Zalfa F, Eleuteri B, Dickson KS, Mercaldo V, De Rubeis S, di Penta A, et al. A new function for the fragile $\mathrm{X}$ mental retardation protein in regulation of PSD-95 mRNA stability. Nat Neurosci. 2007;10:578-87.

Zhang M, Wang Q, Huang Y. Fragile X mental retardation protein FMRP and the RNA export factor NXF2 associate with and destabilize Nxf1 mRNA in neuronal cells. Proc Natl Acad Sci U S A. 2007;104:10057-62.

Zhao W, Chuang SC, Bianchi R, Wong RK. Dual regulation of fragile $\mathrm{X}$ mental retardation protein by group I metabotropic glutamate receptors controls translation-dependent epileptogenesis in the hippocampus. J Neurosci. 2011;31:725-34. 